\title{
INNOVATIVE FLEXIBLE PRODUCTS IN MICROFINANCE
}

\author{
Carolina laureti* and Michael Hamp**
}

\begin{abstract}
The paper describes innovative microfinance products that combine flexibility features with financial discipline. Those are microsavings, microcredit and microinsurance products and they come from microfinance institutions worldwide. This review shows that service providers are introducing various types of flexibility into financial contracts and that flexibility can be combined with a variety of disciplining mechanisms, such as direct screening and monitoring of clients, financial collateral, reputational incentives, and also psychological pressure. We notice, however, that product flexibility may raise the operational costs for the institutions and have a limited outreach.
\end{abstract}

Keywords: product flexibility, discipline, commitments, and microfinance.

JEL Classification: D03, D82, G21, 012.

\section{INTRODUCTION}

The poor need flexible products that allow transactions adapted to their cash-flow. Such products help the poor to smooth consumption, when income is irregular and unpredictable, to cope with emergencies and cover unexpected expenses. Financial products designed for poor clients should also include some sort of disciplining mechanisms. Disciplining mechanisms encourage clients to make payments duly on time, i.e., savings deposits, loan

\footnotetext{
* Carolina Laureti in Permanent Researcher at the Centre for European Research in Microfinance (CERMi) based in Belgium. E-mail: carolina.laureti@umons.ac.be.

** Michael Hamp is Senior Rural Finance Adviser at the International Fund for Agricultural Development, IFAD.

The authors are grateful to Kristina Czura, Niels Hermes, Marc Labie, Stuart Rutherford and Ariane Szafarz for their valuable comments.
} 
repayments and insurance premium payments. Disciplining mechanisms serve to mitigate asymmetric information problems, for example moral hazard, and to alleviate clients' behavioural inconsistencies, such as lack of selfcontrol, intra-household disagreement, and inattention (Laureti, 2012). Products mixing flexible features with disciplining mechanisms could, indeed, be of great support for poor people, easing money management and improving their welfare (Collins et al., 2009). This paper focuses on innovative marketoriented products that combine these two important features: flexibility and discipline.

In theory, flexibility and discipline cannot coexist in single products. Indeed, flexibility - for example, in the form of grace period in loan repayment or expost contract renegotiation - increases the client's temptation to renege on his or her commitment, discouraging financial discipline (Laureti, 2012). This paper aims at understating how to manage the trade-off between product flexibility and discipline in microfinance. We ask which disciplining devices may be associated with flexible microfinance contracts, in ways that permit the adaptation of transactions to clients' cash needs while at the same time enhancing the clients' financial discipline.

Previous research has studied why rigid microcredit contracts are effective in enhancing discipline. ${ }^{1}$ One of the most discussed mechanisms is the weekly repayment schedule with repayments starting right after the loan is disbursed. It enhances discipline for two main reasons. Firstly, it screens households with multiple sources of income, which are considered less risky (Jain and Mansuri, 2003). Secondly, small payments are easier to manage for poor people (Fisher and Ghatak, 2010). On that regard, studies on impact give contrasting results. Field and Pande (2008) do not find any significant impact on default with weekly vs. monthly repayment schedule; Field et al. (2011) find that grace period increase default; and McIntosh (2008) finds an improvement in repayment switching from a weekly to a by-monthly repayment schedule. Indeed, flexibility can lower (unintentional) default because it makes money management easier for the poor.

On the savings side, Ashraf et al. (2003) describe different disciplining mechanisms set in commitment savings contracts in developing countries. Following Ashraf et al. (2003), other authors - e.g., Ashraf et al. (2005; 2006) and Karlan et al. (2010) - study the impact of some of those mechanisms: posing restrictions on withdrawals, labelling accounts, using deposits collectors, and sending short message service (SMS) reminders to clients. They all

1 See Armendariz and Morduch (2010) for an overview on disciplining mechanisms in loan contracts, used by microfinance institutions in developing countries. 
find a positive effect on clients' savings behaviour. The theory explains that those mechanisms correct some client's behavioural inconsistencies: labelling accounts makes the future more salient (Ashraf et al., 2006); deposit collectors act as a moral imperative for clients to save (Ashraf et al., 2005); and SMS reminders mitigate inattention problems (Karlan et al., 2010). Moreover, SMS reminders can also enhance loan repayment through better financial management (Cadena and Schoar, 2011).

To our knowledge, there is little evidence from the literature investigating ways to make microfinance contracts more flexible. Some contributions come from theoretical models. For example, Tedeschi (2006) proposes to make the dynamic incentive mechanisms more flexible by adapting the punishment phase to the clients' type. Sadoulet (2002) shows that reputational mechanisms should guide institutions that provide repayment insurance to borrowers. However, empirically we do not know if those mechanisms are truly effective.

There exists also a literature describing successful flexible contracts in microfinance, with the most notable example being SafeSave (CGAP, 2000; Rutherford, 2011). Most of that literature, however, focuses on single case studies, with a few exceptions, such as CGAP/IFAD (2006b) and Ashraf et al. (2003). Our paper is mostly related to Ashraf et al. (2003) as they describe a list of microfinance products worldwide. However, they are focused on savings and are only interested in disciplining mechanisms. Differently, our paper analyses both discipline and flexible features of a wide variety of financial products addressed to the poor in developing contexts.

Searching on the internet extensively - for donors' studies, practitioners' reports and microfinance institutions and networks' websites - we identified nine innovative practices covering credit, savings, and insurance services. Those innovative practices have one common aspect: they mix flexible features and disciplining devices. The paper highlights and compares the flexible features and the discipline mechanisms for each of the nine products. We individuate different types of flexible contract features, in line with Laureti (2012). Moreover, we identify some disciplining mechanisms that could be associated with flexible products.

The rest of the paper is structured as follows. Section 2 discusses the trade-off between flexibility and financial discipline; it is conceptual and provides a framework for the discussion. Section 3 describes nine innovative products, focusing on the flexibility features and the disciplining mechanisms. Section 4 draws lessons from these analyses and presents best practices for developing pro-poor microfinance products. Section 5 sums up the findings and presents our conclusions. 


\section{THEORETICAL INSIGHTS FROM THE LITERATURE}

Financial discipline is a desirable behaviour of clients, characterized by their obedience to financial commitments, which is encouraged thanks to some disciplining mechanisms. In the literature, commitments are arrangements that channel the client's decisions by making certain choices more costly, sometimes even infinitely expensive, and by providing incentives that promote certain choices (Amador et al., 2006; Bryan et al., 2010). For the sake of clarity, in this discussion we call disciplining mechanisms those devices associated with commitment products, which encourage clients to fulfil their obligations. In the same sense, commitments are credible when the disciplining mechanisms associated with them are strong enough to push clients to make the necessary effort to fulfil their obligations.

Credit, savings, or insurance contracts are different types of financial commitments, which could be associated to a range of disciplining mechanisms, of various strength. For example, microcredit contracts are commonly considered credible commitments, driven by various disciplining mechanisms, e.g., social pressure, holding of financial collateral as security for loans, and dynamic incentives. Also the weekly instalment schedule ubiquitous in microcredit contracts is considered an effective disciplining device, imposing discipline through the regularity and frequency of payments and meetings (Armendariz and Morduch, 2010). Commitment savings plans may fix times and amounts for deposits and/or impose restrictions on withdrawals (Ashraf et al., 2003). Disciplining mechanisms associated with commitment savings should encourage clients to make deposits duly on time, for example, by sending staff to the clients' home or workplace for collection of deposits; disciplining mechanisms could also impose fees for early withdrawal of funds prior to a fixed target date.

Credible commitments are important for poor households who have difficulty in saving. ${ }^{2}$ Such difficulty can be due to lack of self-control, inattention to planning, or family members asking for money insistently. The proliferation of informal financial systems, such as rotating savings and credit associations (ROSCAs) and deposit collectors, shows that poor people value commitments (Rutherford, 2000; Johnson, 2004; Guerin, 2011). Also rigid microcredit contracts with a weekly repayment schedule are popular among

2 "Difficulty in saving" is conceptually different from unwillingness to save or inability to save. The poor want to save and do actually save. The difficulty they have in saving is due to temptation or attention problems or social pressure. Having the poor engage in credible commitments may attenuate those problems. Seminal papers on this topic include Strotz (1955), Thaler (1985) and Laibson (1997). Bryan et al. (2010) provide a literature review on commitments. 
people with self-control problems (Bauer et al., 2012). There is evidence showing that commitment savings products incorporating appropriate disciplining mechanisms effectively help the poor to reach their savings targets (Ashraf et al., 2005, 2006; Karlan et al., 2010).

Given that the poor have the capacity and the willingness to save, credible commitments would help them to build up large lump sums (Rutherford, 2000; Adams, 2009), for covering lumpy expected expenditure, such as the payment of school fees or for life-cycle events like marriages or funerals (Collins et al., 2009). Stored funds could also help the poor to cope with risk. In this case, commitment products should include some flexibility features.

Product flexibility refers to the ease with which financial transactions are adapted to clients' cash flow (Collins et al., 2009). Contrary to the typical disciplining mechanisms used in microcredit products, flexible products allow for grace periods in loan repayment, provide for adaptable instalment schedules to avoid burdening clients with high repayments in difficult times, and allow for loan prepayment, loan renegotiation in the case of an income shock, and loan refreshing at some point during the loan cycle (Collins et al., 2009). In the case of savings services, flexibility corresponds to the absence of a minimum balance requirement, the voluntary nature of savings and, generally, to the possibility of making deposits and withdrawals of variable amounts conveniently and at no costs.

Flexibility is important for the poor because it helps them to manage money, e.g. smoothing consumption, coping with risks, and taking advantage of unexpected investment opportunities. For example, ad hoc payment schedules permit households to save ${ }^{3}$ cash as soon as it is available, avoiding the temptation to spend it on miscellaneous expenses (Ravi, 2006). Allowing for a grace period in loan repayment would expand the range of investment opportunities, including projects that require a lengthy gestation period before realizing consistent profits (Field et al., 2011). Allowing expost contract renegotiation, earlier withdrawals in a fixed savings plan, or providing for emergency loans would help poor clients to deal with income shocks and unexpected expenditure needs (Meyer, 2002; Karlan and Mullainathan, 2006; Collins et al., 2009; Shoji, 2010). Permitting prepayment of loans or offering passbook savings accounts with no restriction on deposits would give the poor a means of investing unexpected small financial surpluses.

For microfinance institutions (MFIs), clients' discipline serves to ensure that lenders are more aware of borrowers' financial situations, reducing the

3 Whether saving up (setting money aside until it grows into a useful large sum) or saving down (setting money aside to repay a loan) (Rutherford, 2000). 
likelihood of clients' delinquency and default. For this purpose, institutions use a variety of mechanisms to screen, monitor and provide incentives to borrowers. For example, joint liability, frequent and regular repayment schedule of loans, and compulsory savings serve at this purpose (Armendariz and Morduch, 2010). Also the use of clients' credit history by loan officers is a subjective and implicit credit scoring mechanisms for evaluating credit risk (Scheiner, 2004). Flexibility is good because it increases clients' satisfaction, reduces client dropout, and encourages new clients to take up the products. Moreover, helping the poor to manage their money should reduce unintentional defaults and over-indebtedness (Chaudhury and Matin, 2002; Schicks, 2010).

Generally, a more market-oriented approach would help the industry both to increase its social impact and to improve long-term institutional sustainability. Indeed, product design can serve as a powerful targeting mechanism, because it determines the type of clients attracted and the extent of the benefits clients receive from financial services (Woller, 2002; Johnson, 2005; Copestake, 2007). Developing client-led financial products might help MFIs to attain their social mission - for example, avoiding the perverse phenomenon known as mission drift (Armendariz and Szafarz, 2010). It guarantees that a larger portion of productivity surpluses is attributed to poor clients (Labie, 2009; Hudon and Perilleux, 2010).

Product flexibility and clients' discipline are both important in microfinance. However, it seems they are hardly reconciled in single financial products. There are two major constraints. Firstly, in theory product flexibility should raise the clients' temptation to renegade their commitment (Laureti, 2012). Consequently, in order to be incentive-compatible, the terms of the contracts - such as the maturity, the amount, the payments schedule, the interest rates, etc. - as well as the disciplining mechanisms should be adjusted to take into account the increased temptation. For example, Fisher and Ghatak's (2010) model shows that low frequency repayment schedule decreases the incentive-compatible loan size for a given set of disciplining mechanisms. Sadoulet (2002) shows that repayment insurance should be provided only after the first loan cycle, and only to those clients who achieve a good reputation for loan repayment. Tedeschi's (2006) model proves that the punishment phase should be adapted to the client type. Ceteris paribus, it should be higher for those clients who value the lending relationship little.

Secondly, product standardization simplifies operations, limits the risk of staff fraud, and facilitates liquidity management (Sadoulet, 2002; Karlan and Mullainathan, 2006; Jeon and Menicucci, 2011). In contrast, flexibility makes microfinance operations more complex. For example, higher on-demand assets and liabilities increase the institutions' exposure to interest rate risk. Al- 
so liquidity risk would increase. Standard disciplining mechanisms - e.g., joint liability, weekly payment schedule, compulsory savings, dynamic incentives, etc. - help influencing clients to act more cost-effective. They motivate clients to make payments on time, without the MFIs incurring in excessively high operational costs. However, those mechanisms do not permit the adaptation of financial transactions to the clients' cash needs.

This paper aims at individuating alternative ways to encourage clients' discipline. Most importantly, disciplining mechanisms should be compatible with some flexibility product features. The approach we take is practical and constructive: by looking at existing innovative products that combine flexibility features with disciplining mechanisms, we should get some new ideas on how it is possible, in practice, to combine product flexibility with clients' discipline. The main contribution of this paper is, indeed, to assemble a set of examples of flexible financial products offered by microfinance institutions worldwide, including savings, credit, and insurance products.

\section{PRODUCTS BALANCING FLEXIBILITY AND DISCIPLINE}

This section lists nine innovative products/practices of microfinance institutions (MFIs) worldwide, covering microcredit, microsavings, and microinsurance services. These products are innovative primarily because they combine flexibility features with mechanisms to ensure clients' discipline. Factors such as technology used and originality of products' features played a role in the selection process, but to a lesser extent.

Key information is provided on each product: name/type of product; short description; relevance for the poor, which we call motivation; flexibility features; and disciplining mechanisms (i.e., financial discipline features). Flexibility and discipline features are discussed in detail and information about the provider is given, including its location, background, outreach, etc. In the appendix, we provide some tables synthesizing the main products' features.

\subsection{SafeSave and ShohozShonchoy's savings and loan accounts (Bangladesh)}

SafeSave ${ }^{4}$ was founded by Stuart Rutherford in Dhaka, Bangladesh in 1996, offering one basic product: a passbook savings account, which allows maximum flexibility on deposits and withdrawals (any amount at any time).

\footnotetext{
4 www.safesave.org.
} 
If clients wish, they may take out a loan, the amount of which is linked to the client's savings balance and increases with good repayment history. Loans are repaid flexibly with no fixed duration (the minimum monthly payment is the interest).

Loan repayment and savings deposits are enforced through three main mechanisms. Firstly, client must provide financial collateral (savings balance should be at least one third of loan outstanding). Secondly, the loan ceiling increases with good credit history, which is progressive lending. Thirdly, the MFI's staff visits clients once or twice a day at their home or workplace for collecting savings deposits and loan repayment.

As of January 2011, SafeSave payment collectors are 66, all of them women hired from low-income neighbourhoods. SafeSave had 9 branches serving 15750 clients living in the slums of Dhaka. Clients held USD 709000 in their savings accounts, with an average savings balance per client of USD 45. More than half of SafeSave clients (8 600) hold loans, worth a total of USD 614 000, with an average outstanding balance of USD 71 per borrower. ${ }^{5}$

Following SafeSave's experience, in 2002 a rural version called ShohozShonchoy 6 was founded in the village of Hrishipara in central Bangladesh. Whereas SafeSave aims to grow, the Hrishipara experiment is kept deliberately small, so as to test a number of different products. Today it has around 1300 clients and 9 collectors.

Its most popular product is called P9. P9 is designed to help clients build up savings while providing liquidity through loans. As for SafeSave, loans do not have any fixed repayment schedule or maturity. However, P9 has another interesting flexible feature: clients may also top-up their loans, i.e., they may borrow as much as they have repaid. For disciplining clients, also P9 adopts financial collateral, progressive lending, and payment collectors. The peculiarity is that one third of any fresh loan and loan top-up is deposited in a long-term savings account, where withdrawals are restricted until savings balance reaches a fixed target amount. ${ }^{7}$

As of May 2011, 724 active clients have P9 accounts in Hrishipara holding 3.18 million taka in loans (4 393 taka per client, equivalent to roughly USD 63) and 4.24 million taka in savings (5 863 taka per client, equivalent to roughly USD 84).

5 www.safesave.org, accessed 20 June 2011. Exchange rate USD $1=70$ Taka.

6 www.thepoorandtheirmoney.com.

7 Since early 2010, a version of P9 called Easysave has been piloted in Kenya, running on the M-Pesa mobile money platform. In October 2010 a third version of P9 was introduced in Kalyanpur slum of Dhaka (http:/ /sites.google.com/site/trackingp9/, accessed 20 June 2011). 
Table 1 and 2 in the appendix provides a synthesis of the main products' features and a detailed comparison of SafeSave and ShohozShonchoy P9 products.

\subsection{Bank Rakyat Indonesia'slottery-linked savings account (Indonesia)}

PT. Bank Rakyat Indonesia (Persero) (BRI) is a state-owned commercial bank $^{8}$ and one of the most successful examples of microsavings mobilization in developing countries (Seibel et al., 2010). BRI's most popular savings account is called Simpedes in rural areas and Simaskot in urban areas.

Its flexibility features are highly attractive to the poor: no fee to open the account, no minimum balance, no compulsory deposits or withdrawal restrictions and interest paid monthly on all but the smallest balances (less than USD 10). The most innovative feature of Simpedes accounts is its linkage to a lottery. Twice a year BRI issues free lottery tickets to Simpedes account holders, the number depending on the holder's minimum monthly account balance. As the lotteries are held in the branches, winners are located within a small area and most local people have either won a prize or know someone who has, which makes the lotteries very popular. The lottery is a disciplining mechanism. Indeed, it motivates clients to make savings deposits, as larger are savings balance higher is the probability to win the lottery (see table 3 in the appendix for a description of BRI products' main features).

As of the end of March 2011, BRI had 28.85 million savers, more than 20 million of them holding Simpedes accounts (Oleh Donald Banjarnahor, 2011).

\subsection{Fixed savings plans by Vivekananda Sevakendra Sishu Uddyon (India)}

Ashraf et al. (2003) mention various financial institutions around the world that offer fixed savings vehicles, including Vivekananda Sevakendra Sishu Uddyon (VSSU) in India. We selected VSSU for the variety of fixed savings plans it offers - daily, weekly, monthly and term deposits - and for their contractual terms and conditions, which together appear to offer a good balance between discipline and flexibility. ${ }^{9}$

VSSU savings plans are medium- to long-term and require a minimum deposit of USD 0.2 to USD 1 per period. In addition to enforcement features

\footnotetext{
8 www.bri.co.id. BRI became publicly listed on November 2003. By the end of 2009, the Indonesian Government owned $56.77 \%$ of its shares, with the remaining shares held by public investors (BRI, 2010: p. 3).

9 www.vssu.in and VSSU (2009).
} 
typical of such products, such as pre-planning of a regular deposits schedule, VSSU visits clients at their doorstep to collect deposits, so to encourage savers' financial discipline.

Account holders are permitted to close their accounts or to withdraw some money prematurely with respect to the predetermined savings target. This provides the degree of flexibility needed to make the savings plans attractive to the poor clients, being a safety net for urgent unexpected expenses. The temptation for clients to renege on their commitment is balanced by financial sanctions for premature withdrawal or account closure. Charges are imposed only if such failings occur within the first 12 months of contracts. It permits to mitigate the temptation to pull out of the commitment, which is highest in the first period of the contract.

VSSU reaches 380 villages in West Bengal. It has 15 branches and has 56 staff members. In fiscal year 2008/09 it had 17051 active depositors and a cumulative total of 77737 depositors (VSSU, 2009).

Tables 4,5 , and 6 in the appendix provide a synthesis of VSSU products' features.

\subsection{Susu collectors and Barclays Bank in Ghana}

Informal financial devices can offer flexibility and convenience to local communities. However they are mostly unreliable and perform poorly, offering a limited variety of financial services and little in the way of funds. Linking formal and informal financial providers could improve the service by combining the strengths of the two types of institution (Pagura and Kirsten, 2006). This is the rationale behind the linkage between susu collectors and Barclays Bank in Ghana.

Susu collectors are a traditional form of finance practiced in western Africa for over three centuries. It is particularly diffused in Ghana, where there are more than 4000 susu collectors, each of whom have between 400 and 2000 clients. ${ }^{10}$ Susu collectors act as mobile mini-bankers, collecting a predetermined amount of money from each client on a daily or weekly basis over an agreed period, typically one month. At the end of this period, the accumulated savings are returned to the depositor, less a small commission for services (usually equivalent to one day's deposit). Some susu collectors combine deposit-taking with provision of small loans to their clients. ${ }^{11}$

10 In 2008 the susu industry was valued at approximately GBP 75 million (USD 160 million) (Barclays Bank, n.d.a).

11 See Aryeetey and Steel (1995) on collectors in Ghana. 
The loan and savings services offered by susu collectors to local communities in Ghana are convenient and flexible in that they lack bureaucracy and paper work, provide a door-step service, and allow changes in their informal contract terms to meet clients circumstances. They promote financial discipline through the daily visit of collectors to the clients' homes. Close clients monitoring is possible thanks to the physical and cultural proximity of susu collectors to the local economy and their clientele; it discourage clients from shirking strategically on their commitments, enhancing financial discipline (see table 7 in the appendix for a synthetic description of products' salient features).

Since November 2005 Barclays Bank ${ }^{12}$ in Ghana has been providing savings services and investment capital to susu collectors to facilitate their financial intermediation activity with the rural communities. The number of collectors participating in the Barclays initiative increased from 100 in two regions in the first year to more than 500 across the country by 2007. Considering that susu collectors usually have between 400 and 2000 clients, the programme has reached an estimated 200000 to 1000000 clients of susu collectors in 2007 (Osei, 2007).

\subsection{Innovative m-banking products linked to M-Pesa wallet (Kenya)}

Branchless banking through mobile phones (m-banking) is probably the most promising innovation in rural finance in the last few years. Using a network of retail agents and the existing mobile phone infrastructure, potentially even distant and sparsely populated areas can be reached with reliable banking services. The first wave of branchless banking efforts focused on providing payment and money-transfer services. The next challenge is to link mobile money with a full range of banking services (CGAP, 2010; Pickens, 2010).

Safaricom, ${ }^{13}$ the mobile network operator behind M-Pesa in Kenya, allows its 13 million customers to transfer money via their mobile phones and through the countrywide network of more than 23000 agents (Safaricom, 2010). Today, Safaricom, in partnership with a variety of operators (e.g., banks, non-profit organizations, insurance companies, health-service providers, etc.), is piloting innovative m-banking products. Among those, we selected two innovative services for their relevance to the focus of this paper: M-Kesho, a savings account provided by Equity Bank that also gives flexible access to loan and insurance facilities (Equity Bank, 2011); and Mamakiba, a savings

12 Barclays Bank is a multinational bank group with headquarters in London, UK, and operations in more than 50 countries (http:/ / group.barclays.com/Home).

13 http://www.safaricom.co.ke/. 
plan for pregnant women provided by Jacaranda Heath Clinic and Multiple Choices Labs (Gmimano, 2010).

M-Kesho is a bank account linked to a client's M-Pesa account. This permits holders to store money and also to tap into loan and insurance facilities. There are no fee for opening an account, no minimum balance, no monthly fee, and fees for withdrawals but not for deposits. All the transactions occur electronically, through M-Pesa wallet. Clients can also request small emergency loans through the mobile phone. To evaluate a client's creditworthiness, Equity Bank uses a credit scoring system based on the balance and transactional history of the customer. M-Kesho was launched in May 2010 and after only 3 months 455000 people had opened accounts, though activity on these accounts remains low (Radcliffe, 2010).

Mamakiba is a flexible savings plan designed to help pregnant women to pay for their maternal health needs. Flexible features include: the possibility to decide the amount and periodicity of payments and the savings target; it permits to take into account the woman's cash availability and health needs; moreover, payments are actually not compulsory, since they can be skipped without any penalty. Thus, what distinguishes Mamakiba from a usual flexible savings account? Three disciplining mechanisms encourage savings. Firstly, women receive support in planning their financial resources. Secondly, small message service (SMS) reminds women to save, confirms deposits, and provides updates of total savings. Thirdly, savings are blocked for a specific use, which should be a further encouragement for savings. The programme was launched in 2008 and is still in its pilot stage. It targets approximately 25-50 women per month, from low to low-medium income levels (Center for Health Market Innovation, 2011).

Table 8 in the appendix compares M-Kesho and Mamakiba's main features.

\subsection{Seasonal loans by Confianza (Peru) and Banco Los Andes ProCredit (Bolivia)}

Expenses for agricultural activities and income from them are typically seasonal and depend on crop and livestock cycles. As a result, the rigid disbursement and repayment schedules of standard microcredit contracts are not well suited to financing agriculture. A study by CGAP/IFAD (2006a, 2006b) assessed nearly 80 rural finance institutions worldwide to identify successful, sustainable agricultural microfinance products. Confianza ${ }^{14}$ in

14 www.financieraconfianza.pe. 
Peru and Banco Los Andes ProCredit ${ }^{15}$ in Bolivia are among those identified as delivering such products in Latin America.

Both institutions offer short-term loans customized to clients' circumstances, with disbursements and repayments tailored to the income and expenditure cycles of agricultural production. Confianza offers emergency lines of credit to clients with good repayment histories, whereas Banco Los Andes emphasizes its rapid allocation and disbursement process.

Both institutions adopt a strategy of strict credit discipline. Confianza poses strict lending requirements, serving only households with a diversified income stream, and monitors loans closely through a network of loan officers in the field. Banco Los Andes has established a strong reputation for not tolerating delinquency; loan officers visit clients immediately after the first missed payment. It charges high interest rates to clients who have defaulted on payments and lower interest rates to clients in good standing. It has also adopted a broad approach to collateral, focusing on the value of pledged assets to the borrower rather than the recovery value for the lender.

As of the end of December 2010, Confianza had 10250 rural clients, equivalent to 13 percent of its total active clients (75 813). Rural clients had loans totalling USD 25 million, almost 19 percent of the institution's total gross loan portfolio; average loan per rural borrower was USD 2 455, higher than the institution's average loan. Banco Los Andes ProCredit reported that its agricultural credit portfolio amounted to USD 5834000 at end December 2010, equal to only 1.5 percent of its total gross loan portfolio. ${ }^{16}$

Tables 9 and 10 in the appendix provide the products' main features and data on outreach.

\subsection{Rural credit from Bank for Agriculture and Agricultural Cooperatives (Thailand)}

In addition to predictable seasonality of income and expenditure, agriculture is subject to high systemic risk, which is usually co-variant, e.g., natural disasters such as flood and drought, leading to market price volatility. These risks lead to a high degree of uncertainty in smallholder farmers' income, which is usually coupled with a lack of appropriate financial strategies for consumption smoothing. Moreover, raising agricultural productivity requires long-term investments. According to a FAO study (FAO, 2003), state development banks and member-owned institutions, such as Thailand's

15 www.losandesprocredit.com.bo.

16 http://www.losandesprocredit.com.bo/resultadocifras.aspx, accessed 3 August 2011. 
Bank for Agriculture and Agricultural Cooperatives (BAAC), 17 are the most successful in providing such long-term financing for agriculture.

BAAC provides smallholder farmers with short-term loans (6-18 months) for seasonal needs and medium- and long-term loans for financing investment (up to 20 years in the case of purchase of land and machinery) (Saila, 2010). BAAC allows clients to reschedule their loans if they face major repayment difficulties due to flood, drought, etc. (Townsend and Yaron, 2002). To limit moral hazard, credit officers in the field monitor clients' circumstances and punitive interest rates are applied to cheaters.

BAAC protects farmers' income against price volatility through farm income guarantee schemes covering the three main cash crops - rice, cassava and maize. ${ }^{18}$ Under the schemes farmers are compensated for the differences between the reference crop prices and guaranteed prices set by the government. To limit fraud, inspection committees hold meetings at the village or community level to publicly verify and confirm the farmers' farm size and crop production volume (see table 11 in the appendix for a synthesis of BAAC products' salient features).

As of March 2010, a total of 6.10 million farm households had access to BAAC's credit services. The gross loan portfolio to farm households was 475.4 billion baht (approximately USD 16 billion at July 2011 exchange rate), of which 95 per cent (precisely 449.7 billion baht) was loaned to individual farmers (BAAC, 2010). A total of 3.8 million farmers were entitled to receive compensation through the income guarantee scheme, worth 35.4 billion baht (BAAC, 2010: p. 165).

\subsection{Housing microfinance and other long term loans by the Indian Association of Savings and Credit (India)}

Created in 1998, the Indian Association of Savings and Credit (IASC) ${ }^{19}$ offers long-term credit to cover big-ticket expenses for various purposes business, housing, education, etc. - to poor clients.

Loans for economic activity are differentiated between farm and nonfarm businesses and are issued for 3 years. Housing loans are available both for repair and maintenance and for the construction of a new house, with the maturity varying between 2 and 15 years. Loans are also available for educa-

\footnotetext{
17 www.baac.or.th.

18 This scheme was introduced in 2009 to replace the crop pledging scheme the bank operated previously.

19 www.iasc.in.
} 
tion expenses, to cover medical emergencies, for marriage expenses, for disaster mitigation, for redemption, etc..

For encouraging financial discipline, clients are organized in self-help groups. The groups must show a good credit record, regular meeting participation and internal management capacity for at least one year before becoming eligible for loans. The groups must also have a minimum amount of savings balance before they can link with IASC. Other features include: regular monthly instalments; a security deposit of 5 percent; possibility to pay off the loan early, but the institution charges a fee for it.

By March 2010, IASC had 24 branches covering 875 villages. IASC website reports over 34000 active borrowers in 6513 groups (see table 14 in the appendix). IASC issued 30000 loans in 2009-10 with a total value of 307.9 million rupees (USD 7 million) and an average loan size of 10264 rupees (USD 230). Approximately 90 percent of members of self-help groups have an average individual income between 1000 and 3000 rupees per month (USD 22-67) (Centre for Micro Finance, n.d.).

Tables 12, 13, and 14 describe the products' main features and provide data on outreach.

\subsection{VimoSEWA's gender-sensitive composite microinsurance product (India)}

The poor are vulnerable to numerous risks and often do not make a distinction between coverage for their person or their income-generating activities (Churchill, 2011). Therefore, SEWA (Self-Employed Women's Association ${ }^{20}$ in India developed an integrated insurance programme, called Vimo SEWA. Vimo SEWA is specially designed to cover those risks affecting women. It is voluntary for SEWA members and their families: it provides life insurance, hospitalization, accident and asset insurance.

The SEWA composite insurance product has a number of innovative flexibility features. Clients can choose between various insurance schemes that differ in the amount of the annual premium and benefits. SEWA gives clients the possibility to pay their premium in cash or from the interest on fixed deposits. Payments can be annual, quarterly or monthly. SEWA, along with Life Insurance Corporation (LIC) of India, has also introduced a special plan, "JeevanMadhur", which is a simple savings-linked life insurance plan where the individual member pays premiums annually. Recently, SEWA has started to send members SMSs to remind them when it is time to pay their premiums and to give members no-claims discounts (see table 15 in the appendix).

20 www.sewainsurance.org. 
VimoSEWA began with 7000 members in 1992, and currently has 120000 members, a smallnumber of clients considering the Indian context. Until recently, half of the members dropped out each year. The renewal rate has now increased to 60 percent, and SEWA is aiming to bring it to 80 percent.

\section{LESSON LEARNED}

The practices we have reviewed show that flexibility - adaptability of transactions to clients' cash flow - can have various forms. Loans of Confianza and Banco Los Andes Procredit allow financial transactions to be tailored to clients' seasonal cash needs. Disbursement and repayment, however, are predetermined; clients commit to those and are not allowed to alter those commitments. In contrast, BAAC offers the possibility to adjusting the loan payment schedule in the event of emergencies and negative shocks; VSSU allows early withdrawals or premature account closure on its fixed savings plans at the costs of some fees; and IASC allows clients to pay off loans early, but charges a fee. Safesave in Bangladesh offers a different type of flexibility. SafeSave's loans do not set any repayment schedule and do not have any maturity. There is no commitment to a given plan, instead clients are given ample discretion.

These different types of flexibility have implications for the credibility and effectiveness of the commitments. Seasonal loans are a pure commitment and should encourage discipline and lessen concerns of weakness in management information, fraud by staff, and liquidity management. However, they may be less effective than standardized rules that impose frequency and regularity of transactions and meetings. Ex post contract renegotiation weakens the credibility of commitments and aggravates temptation issues. Finally, purely flexible savings accounts do not impose any commitment.

In all the types of flexibility - i.e. seasonal loans, ex-post contract renegotiation, and loans-and-savings flexible accounts - screening, monitoring, and/or incentive mechanisms adopted by the MFIs are quite stringent, which should assure financial discipline. Confianza and Banco Los Andes Procredit lend only to households with diversified income sources, monitor client accounts rigorously, and have a rigid policy toward default. BAAC has adopted a different approach, requiring physical or social collateral from borrowers as a covenant, and uses its staff in the field to verify clients' circumstances in case of request to reschedule a loan; cheaters are faced with punitive interest rates. SafeSave uses financial collateral, clients' credit histories as well as frequent and regular clients' visits. 
We individuate three main ways to combine flexibility and discipline. Firstly, MFIs adopt intensive information lending technologies. For instance, Confianza and Banco Los Andes Procredit should know each customer characteristics, in order to screen those with diversified income sources. Similarly, BAAC's should monitor clients directly, for assessing when default is justified. It is also emblematic that three out of the nine products/practices described in this paper employ deposit collectors to enforce payments, either for loan repayment or savings deposits (i.e. SafeSave, Barclays Bank, and VS$\mathrm{SU})$. Although collectors provide a highly convenient service for clients, they are a cost to the MFI, requiring a large number of staff covering considerable distances in order to reach each client daily. To reduce the cost, both SafeSave and Barlays Bank employ (low-paid) local people, through whom they gain access to locally embedded relations and valuable information. SafeSave hires staff from the same slums where clients live; and Barclays Bank hires (i.e. links to) existing susu collectors. Generally, direct screening and monitoring should be challenging in developing contexts (Viganò, 1993) and bring relevant operational costs for the MFIs.

Secondly, institutions play on setting various economic sanctions as an incentive to motivate clients' discipline. The sanctions are negative or positive. A few MFIs apply penalizing interest rate to bad borrowers (BAAC, Confianza); IASC impose a fee for early loan repayment; VSSU ask a fee for early withdrawal; and SafeSave threats clients to seize their savings. ${ }^{21}$ Finally, BRI rewards clients with high savings balances, through a lottery.

Thirdly, adopting soft commitment ${ }^{22}$ is another way to combine discipline with flexible financial products. The most notable example is the $\mathrm{m}$ banking savings plan for pregnant women, Mamakiba. It is not a compulsory savings plan, offering the same degree of flexibility as passbook savings accounts (such as those offered by SafeSave). However, it employs a variety of soft commitment devices to encourage financial discipline. First, the savings calculator helps clients to plan deposits. Second, SMSs sent through mobile phones remind people to pay, provide updates on savings balances, and

21 Collins et al. (2009: p. 182) explain the value of financial collateral, i.e. linking (voluntary) savings to loans: "Although uncollateralized lending has been one of the proudest boasts of the microfinance movement, the judicious use of financial collateral can make loans more usable for the poor: the diaries show that many poor people do not object to 'borrowing back their own savings' partly because they value the savings so highly that they would rather borrow against them than draw them down, and partly because having the savings reassures them that should difficulties arise they can set their loan off against their savings".

22 Bryan et al. (2010) distinguish between "soft" and "hard" commitments: soft commitments impose a psychological cost, whereas hard commitments impose an economic cost. 
overcome inattention problems, for example when clients forget when payments are due; they also increase salience of future expenditure needs (Karlan et al., 2010; Cadena and Schoar, 2011). Third, tying savings to a specific use may encourage deposits. Indeed, specially labelled accounts encourage saving because of mental accounting effects (Thaler, 1985).

\section{CONCLUDING REMARKS}

Flexibility serves to facilitate consumption smoothing and coping with risk. Commitments accompanied with appropriate disciplining mechanisms serve to encourage that clients make payments - savings deposits, loan repayments and insurance premium payments - duly on time. This review shows that there are ways the microfinance industry can offer flexible financial products that also encourage clients' discipline.

Generally, the introduction of flexibility requires MFIs to adopt appropriate disciplining mechanisms for encouraging clients' to save (up and down). Regarding loan contracts, introducing flexibility requires MFIs to adopt rigorous lending policies. It should balance the increased temptation to default. For example, MFIs should concede flexible repayment schedule only to the best clients; ask for more collateral; deploy more staff in the field to monitor clients rigorously; and generally raise the sanctions for default.

Regarding savings, our review points to the important role of soft commitments in enhancing discipline, i.e., commitments associated with disciplining mechanisms inflicting psychological sanctions to the individual. Such soft disciplining mechanisms include tools to help clients to plan their savings, visits from deposit collectors or SMSs to remind clients to make deposits and loan repayments, and application of mental accounting principles through specially labelled accounts, for example. These mechanisms should encourage clients to save and, at the same time, leave them some flexibility to facilitate their money management. Indeed, we see soft commitments as one of the most promising ways the microfinance industry could mix flexibility and enforcement in microsavings products.

This review suggests two potential trade-offs when balancing flexibility and discipline, mainly for the credit market. First, flexibility may result in higher costs for enforcing loan contracts, especially for acquiring information on clients to evaluate their preferences, repayment capacity, etc. Considering that, in developing country contexts, the unit of analysis is commonly the entire household, rather than an individual, gathering such information may be a major problem for MFIs. Second, MFIs tend to offer flexibility to 
privileged clients, e.g. households with diversified cash flow (Confianza and Banco Los Andes), households with large savings and good credit history (SafeSave and IASC), household with collateral (BAAC) and households that already have access to informal finance channels (Barclays Bank). This will tend to exclude poorer, more vulnerable households, which could have benefited the most from access to credit.

The microfinance literature indicates that market-oriented approaches offer important gains in both long-term institutional sustainability and social impact. This review shows that flexibility increases MFIs'costs but does not seem to bring with it a broadening of their client base. Research is needed to verify these perceptions, perhaps through collection of rigorous empirical evidence. In-depth case-studies of one or more of the institutions covered by this review could help understand the costs of flexibility for the MFIs, whether these costs are passed on to the clients through, for example, higher interest rates on loans, and the typology of clientele to which flexibility is addressed. Randomized field experiments would be the best methodology to evaluate the impact of product flexibility on variables such as clients' default and satisfaction rates.

The microfinance practices we have reviewed combine flexibility and discipline within one product. Alternatively, flexibility and discipline could be offered in separate products accessible simultaneously to clients. For example, MFIs could offer emergency loans to good clients; such loans could be disbursed rapidly and for a short term (e.g., 1 or 2 months) and be designed especially to deal with the effects of an income shock or an unexpected expenditure need (for example, FAI et al., 2011). Flexibility and discipline could be offered simultaneously through two distinct savings products, such as a flexible passbook savings account and a disciplined commitment savings account. The Grameen Bank II System is a good example of this approach. ${ }^{23}$ Clients would use a passbook savings account for day-to-day money management to deposit daily small surpluses and to have fast liquidity access when needed, while the commitment savings account would provide the structure necessary to accumulate a large lumpsum for some future planned expenditure. Cross-selling various financial products would strengthen the relationships between the MFIs and the clientele, bringing comparative advantage to the service providers.

23 Dowla and Barua (2006). 


\section{APPENDIX}

\section{List of Tables}

Table 1: Description of SafeSave and ShohozShonchoy's products

\begin{tabular}{|c|c|}
\hline Product name/type & Savings and loan accounts \\
\hline Description & Passbook savings and loans typically linked to savings balances \\
\hline Motivation & $\begin{array}{l}\text { Help households in their daily cash management and support them in forming } \\
\text { larger lump sums through both savings and loans }\end{array}$ \\
\hline Flexibility features & $\begin{array}{l}\text { - Passbook savings with no or few limitations on withdrawals and deposits } \\
\text { - Flexible loan duration (e.g. either not predetermined or fixed by the clients } \\
\text { themselves) } \\
\text { - No predetermined repayment schedule for loan products }\end{array}$ \\
\hline $\begin{array}{l}\text { Financial discipline } \\
\text { features }\end{array}$ & $\begin{array}{l}\text { - Borrowers must provide financial collateral } \\
\text { - Progressive lending } \\
\text { - Daily visit of staff to clients' home or workplace } \\
\text { - Staff hired in the slums where the clients live } \\
\text { - A few restrictions on withdrawals for clients with loan outstanding } \\
\text { - In some cases, compulsory deposits linked to loan disbursement } \\
\text { - In some cases, higher interest rate for higher savings balance }\end{array}$ \\
\hline
\end{tabular}

Source: Rutherford (2011); www.safesave.org and www.thepoorandtheirmoney.com (accessed 20 June 2011).

\section{Table 2: Comparison of SafeSave basic loan-and-saving accounts, P9-Hrishipara and P9-Kalyanpur}

\begin{tabular}{|l|l|l|l|}
\hline $\begin{array}{l}\text { Terms and } \\
\text { conditions }\end{array}$ & SafeSave & P9-Hrishipara & P9-Kalyanpur \\
\hline $\begin{array}{l}\text { Savings Interest } \\
\text { rate }(+)\end{array}$ & $\begin{array}{l}6 \% \text { per year, for balances } \\
\text { above } 1000 \text { taka }\end{array}$ & No interest on savings & No interest on savings \\
\hline $\begin{array}{l}\text { Obligatory } \\
\text { deposits }\end{array}$ & None & $1 / 3$ fresh loan and top-up & $\begin{array}{l}1 / 2 \text { fresh loan; } \\
1 / 10 \text { loan top-up }\end{array}$ \\
\hline $\begin{array}{l}\text { Restrictions on } \\
\text { withdrawals }\end{array}$ & $\begin{array}{l}\text { Some restrictions to main- } \\
\text { tain partial savings collat- } \\
\text { eral when loans are pres- } \\
\text { ent }\end{array}$ & $\begin{array}{l}\text { Fee for early withdrawals } \\
\text { 2avings balance less than }\end{array}$ & $\begin{array}{l}\text { Loan ceiling reduced for } \\
\text { early withdrawals (before } \\
\text { completion of loan repay- } \\
\text { ment) }\end{array}$ \\
\hline
\end{tabular}




\begin{tabular}{|c|c|c|c|}
\hline $\begin{array}{l}\text { Loan interest rate } \\
(-) \text { and other fees }\end{array}$ & $\begin{array}{l}3 \% \text { of the month-end, de- } \\
\text { clining balance. } \\
\text { Fees: } 20 \text { taka for account } \\
\text { opening; } 5 \text { taka per month } \\
\text { for daily visit service; } 50 \\
\text { taka loan processing fee } \\
\text { for each loan taken }\end{array}$ & $\begin{array}{l}\text { Interest-free loan. } \\
\text { Fees: } 100 \text { taka for account } \\
\text { opening; } 1 \% \text { of borrowed } \\
\text { value for loan disburse- } \\
\text { ment and top-up; } 5 \% \text { of } \\
\text { savings value for early } \\
\text { withdrawal }\end{array}$ & $\begin{array}{l}\text { Interest-free loan. } \\
\text { Fees: } 200 \text { taka for account } \\
\text { opening; } 3 \% \text { for loan dis- } \\
\text { bursement }\end{array}$ \\
\hline Loan duration & No fixed duration & No fixed duration & No fixed duration \\
\hline Loan payments & $\begin{array}{l}\text { Repayment of loan princi- } \\
\text { ple is up to the client; com- } \\
\text { pulsory repayment of } \\
\text { monthly interest }\end{array}$ & No fixed schedule & No fixed schedule \\
\hline $\begin{array}{l}\text { Loan } \\
\text { disbursement }\end{array}$ & $\begin{array}{l}\text { The client's credit limit ris- } \\
\text { es with each loan, provid- } \\
\text { ed all interest has been } \\
\text { paid on time, with the } \\
\text { biggest increases going to } \\
\text { clients who demonstrate } \\
\text { an ability to make regular } \\
\text { loan repayments each } \\
\text { month }\end{array}$ & $\begin{array}{l}\text { Initial loan amount } 2000 \\
\text { taka; standardized in- } \\
\text { crease when loan is fully } \\
\text { repaid; possibility to top- } \\
\text { up the loan before comple- } \\
\text { tion of repayment }\end{array}$ & $\begin{array}{l}\text { Initial loan amount } 5000 \\
\text { taka; standardized in- } \\
\text { crease when loan is fully } \\
\text { repaid; possibility to top- } \\
\text { up the loan before comple- } \\
\text { tion of repayment }\end{array}$ \\
\hline
\end{tabular}

Source: www.safesave.org and www.thepoorandtheirmoney.com (accessed 20 June 2011).

\section{Table 3: Description of BRI's products}

\begin{tabular}{|l|l|}
\hline Product name/type & Simpedes and Simaskot \\
\hline Description & Savings accounts for low-income urban and rural savers \\
\hline Motivation & Provide to low-income people a highly liquid savings account \\
\hline Flexibility features & $\begin{array}{l}\text { - Unlimited withdrawal instantly } \\
\text { - No compulsory deposits } \\
\text { - No minimum balance } \\
\text { - No fee for account opening }\end{array}$ \\
\hline $\begin{array}{l}\text { Financial discipline } \\
\text { features }\end{array}$ & Bi-annual lottery \\
\hline
\end{tabular}

Source: Ashraf et al. (2003). 


\section{Table 4: Description of VSSU's products}

\begin{tabular}{|l|l|}
\hline Product name/type & Fixed savings plans \\
\hline Description & $\begin{array}{l}\text { Daily, weekly and monthly programmed deposit plan (recurrent deposit) and a } \\
\text { one-time saving scheme (term deposit) }\end{array}$ \\
\hline Motivation & Respond to clients' need for planning and long-term savings \\
\hline Flexibility features & $\begin{array}{l}\text { - Various instalment frequencies } \\
\text { - Allows clients to renege on their commitment, e.g. permits premature closure of } \\
\text { savings account or early withdrawal of funds }\end{array}$ \\
\hline $\begin{array}{l}\text { Financial discipline } \\
\text { features }\end{array}$ & $\begin{array}{l}\text { - Regular deposits } \\
\text { - Feposit collector at the client's doorstep }\end{array}$ \\
\hline
\end{tabular}

Source: www.vssu.in (accessed May 2011).

Table 5: Terms and conditions on VSSU savings plans

\begin{tabular}{|l|l|l|l|}
\hline Product type & Term & $\begin{array}{l}\text { Minimum deposit } \\
\text { (rupees) }\end{array}$ & $\begin{array}{l}\text { Rate of interest } \\
\text { (annual, \%) }\end{array}$ \\
\hline Daily scheme & $12-18$ months & 10 per day & $3-4$ \\
\hline Weekly scheme & 100 weeks (24 months) & 10 per week & 6 \\
\hline Monthly scheme & $12-60$ months & 50 per month & $11-12$ \\
\hline One-time scheme & $12-72$ months & 1000 & $11-12$ \\
\hline
\end{tabular}

Source: www.vssu.in (accessed May 2011). Exchange rate USD $1=45$ rupees.

Table 6: Flexibility features of VSSU savings plans

\begin{tabular}{|l|l|l|}
\hline Product type & Premature closure & Premature withdraw \\
\hline Daily scheme & $\begin{array}{l}\text { In case of premature closure, 2\% of in- } \\
\text { terest or a fee of } 60 \text { rupees is deducted } \\
\text { from the deposit amount as penalty }\end{array}$ & $\begin{array}{l}\text { If a withdrawal is made before a given } \\
\text { period (usually 50 weeks or 12 months), } \\
\text { no interest is paid on the amount de- } \\
\text { posited plus a collection fee of 60 } \\
\text { rupees or 4\% of the amount withdrawn } \\
\text { (whichever is greater) is charged }\end{array}$ \\
\hline Monthly scheme & N.d. &
\end{tabular}

Source: www.vssu.in (accessed May 2011). 


\section{Table 7: Description of Barclays Bank's products}

\begin{tabular}{|l|l|}
\hline Product name/type & Susu collectors + Dwediri accounts \\
\hline Description & $\begin{array}{l}\text { The bank offers susu collectors both savings accounts and investment capital for } \\
\text { on-lending }\end{array}$ \\
\hline Motivation & $\begin{array}{l}\text { Facilitate susu collectors' financial intermediation activity (savings and loans) with } \\
\text { the local communities }\end{array}$ \\
\hline Flexibility features & $\begin{array}{l}\text { - Permits adjustment of conditions to changed circumstances, as in emergencies } \\
\text { - Low transaction costs for clients } \\
\text { - Very little or no bureaucracy and paperwork } \\
\text { - Quick turn-around time }\end{array}$ \\
\hline $\begin{array}{l}\text { Financial discipline } \\
\text { features }\end{array}$ & $\begin{array}{l}\text { - Information-intensive mechanism for enforcing payments, i.e., good knowledge } \\
\text { of the local economy and proximity with the clientele and their businesses } \\
\text { - Doorstep service }\end{array}$ \\
\hline
\end{tabular}

Source: Osei (2007); Microfinance Gateway (2010); Barclays Bank (n.d.a, n.d.b); IFAD (n.d.).

\section{Table 8: Description of M-Kesho and Mamakiba}

\begin{tabular}{|c|c|c|}
\hline Product name/type & M-Kesho & Mamakiba \\
\hline Description & $\begin{array}{l}\text { Savings accounts, linked to credit and insur- } \\
\text { ance facilities }\end{array}$ & Savings plans for pregnant women \\
\hline Motivation & $\begin{array}{l}\text { Provide convenient and reliable multipur- } \\
\text { pose bank accounts to low-income cus- } \\
\text { tomers }\end{array}$ & $\begin{array}{l}\text { Help low-income women to save } \\
\text { and prepay for their maternal health } \\
\text { needs }\end{array}$ \\
\hline Flexibility features & $\begin{array}{l}\text { - Transactions through mobile phone } \\
\text { - No account opening fee, no minimum bal- } \\
\text { ance and no monthly charges } \\
\text { - No limits on maximum savings balance } \\
\text { - Access to "emergency" credit on demand } \\
\text { - Access to personal accident insurance }\end{array}$ & $\begin{array}{l}\text { - Transaction through mobile } \\
\text { phone } \\
\text { - No compulsory savings plan and } \\
\text { target } \\
\text { - Flexible use of surplus funds }\end{array}$ \\
\hline $\begin{array}{l}\text { Financial discipline } \\
\text { features }\end{array}$ & $\begin{array}{l}\text { - System of credit scoring for access to loan } \\
\text { - Fee for withdrawals and no fee for de- } \\
\text { posits } \\
\text { - Positive interest rate on savings }(0.5-3 \% \\
\text { depending on balance) }\end{array}$ & $\begin{array}{l}\text { - Calculation of savings plan } \\
\text { - SMS savings reminders and de- } \\
\text { posit alerts } \\
\text { - Savings locked in for a specific } \\
\text { use }\end{array}$ \\
\hline
\end{tabular}

Sources: Equity Bank http:/ /www.equitybank.co.ke/products.php?subcat=128 (accessed 3 August 2011); Mas (2010); Gmimano (2010). 


\section{Table 9: Description of Confianza and Banco Los Andes' products}

\begin{tabular}{|l|l|}
\hline Product name/type & Agricultural loans (short term) \\
\hline Description & Microcredit for financing rural households and their agricultural activities \\
\hline Motivation & Provide sustainable access to credit in rural areas \\
\hline Flexibility features & $\begin{array}{l}\text { - Individual lending } \\
\text { - Loan disbursements made in instalments corresponding with the crop cycle } \\
\text { - Loan repayments are set according to revenue flow } \\
\text { - Loan term is adapted to the crop cycle }\end{array}$ \\
\hline Financial discipline & $\begin{array}{l}\text { - Borrowers must provide some collateral } \\
\text { - Penalty interest rate } \\
\text { - Rigorous loan monitoring } \\
\text { - No tolerance toward default } \\
\text { - Selection of household with diversified income sources }\end{array}$ \\
\hline
\end{tabular}

Source: CGAP/IFAD (2006a, 2006b).

Table 10: Characteristics of loan portfolios of Confianza (Peru) and Banco Los Andes (Bolivia), end of December 2010

\begin{tabular}{|l|l|l|l|}
\hline & & Confianza & Banco Los Andes \\
\hline Total active borrowers & no. & 75813 & 67203 \\
\hline Rural borrowers & no. & 10250 & n.d. \\
\hline Percentage rural & $\%$ & 13.52 & n.d. \\
\hline Gross loans portfolio & USD & 134397509 & 391153418 \\
\hline Rural loans portfolio & USD & 25159786 & $5834000^{+}$ \\
\hline Percentage rural & $\%$ & 18.72 & n.d. \\
\hline Average loan & USD & $1773^{\#}$ & $5837^{*}$ \\
\hline Rural average loan & USD & $2455^{\#}$ & n.d. \\
\hline
\end{tabular}

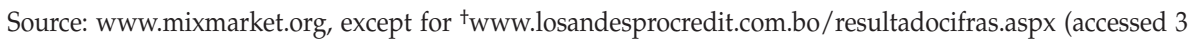
August 2011).

* Authors' rough calculation, as the ratio between the value of the loan portfolio and the number of active borrowers. 


\section{Table 11: Description of BAAC's products}

\begin{tabular}{|l|l|}
\hline Product name/type & Rural credit \\
\hline Description & Short-, medium- and long-term financing for rural households \\
\hline Motivation & Provide demand-based financing and risk-coping devices for rural households \\
\hline Flexibility features & $\begin{array}{l}\text { - Short-, medium- and long-term financing } \\
\text { - Ex post loan renegotiation } \\
\text { - Income pledge for farmers }\end{array}$ \\
\hline $\begin{array}{l}\text { Financial discipline } \\
\text { features }\end{array}$ & $\begin{array}{l}\text { - Monitoring } \\
\text { - Standard collateral } \\
\text { - Credit history }\end{array}$ \\
\hline
\end{tabular}

Source: Townsend and Yaron (2002); FAO (2003); CGAP/IFAD (2006a); Wajananawat (2010).

\section{Table 12: Description of IASC's products}

\begin{tabular}{|l|l|}
\hline Product name/type & Economic loans, housing loan, other loans \\
\hline Description & Long-term loans to cover big-ticket expenses \\
\hline Motivation & $\begin{array}{l}\text { For various purposes: economic activity, housing and other (education, medical } \\
\text { emergencies, debt redemption, revolving fund, disaster mitigation, etc.) }\end{array}$ \\
\hline Flexibility features & $\begin{array}{l}\text { - Long-term loan (12-180 months) } \\
\text { - Loans can be paid off early, albeit at a price }\end{array}$ \\
\hline $\begin{array}{l}\text { Financial discipline } \\
\text { features }\end{array}$ & $\begin{array}{l}\text { - Self-help group-IASC linkage } \\
\text { - Regular monthly instalment } \\
\text { - Pecurity deposit: } 5 \% \text { of the loan amount }\end{array}$ \\
\hline
\end{tabular}

Source: CRISIL (2008) and www.iasc.in (accessed 1 May 2011). 
Table 13: Terms and conditions of some IASC loans

\begin{tabular}{|l|c|c|c|c|c|}
\hline Product type & $\begin{array}{c}\text { Loan } \\
\text { amount } \\
\text { (rupees) }\end{array}$ & $\begin{array}{c}\text { Loan } \\
\text { term } \\
\text { (years) }\end{array}$ & $\begin{array}{c}\text { Interest } \\
\text { rate } \\
\text { (\%) }\end{array}$ & $\begin{array}{c}\text { Approx monthly } \\
\text { instalment } \\
\text { (rupees) }\end{array}$ & $\begin{array}{c}\text { Approx monthly } \\
\text { instalment } \\
\text { (USD)* }\end{array}$ \\
\hline Housing loan & 75000 & 10 & 18 & 1351 & 30.38 \\
\hline New construction & 45000 & 5 & 17 & 1118 & 25.14 \\
\hline Extension & 30000 & 3 & 18 & 1085 & 24.38 \\
\hline Repairs & 30000 & 3 & 18 & 1085 & 24.38 \\
\hline Plot purchase & 15000 & 3 & 18 & 542 & 12.19 \\
\hline Economic loan & 25000 & 3 & 19 & 916 & 20.60 \\
\hline Farm & & & & & 15.64 \\
\hline Non-farm & 25000 & 4 & 15 & 696 & 20.89 \\
\hline Other loans & 25000 & 3 & 20 & 929 & 7.79 \\
\hline Education & 10000 & 3 & 15 & 347 & \\
\hline Wedding & 300 & & & \\
\hline Medical emergency & & & & & \\
\hline
\end{tabular}

Source: www.iasc.in (accessed 1 May 2011). Exchange rate USD 1 USD $=44.48$ rupees.

* Authors' calculation. Monthly payments based on the loan amount, loan term and compounded interest rate. It should give an idea of the income level of the target clientele.

Table 14: Numbers of borrowers and groups obtaining loans from IASC, and value of loans, March 2008 to March 2010

\begin{tabular}{|l|c|c|c|}
\hline & 31 March 2008 & 31 March 2009 & 31 March 2010 \\
\hline No. of active borrowers & 17070 & 19603 & 34321 \\
\hline No. of groups & 4038 & 4841 & 6513 \\
\hline No. of loans issued & 13300 & 20135 & 30000 \\
\hline Value of loan disbursed ('000 rupees) & 112200 & 146200 & 307900 \\
\hline Average value of loan disbursed (rupees) & $8436^{*}$ & $7260^{*}$ & $10264^{*}$ \\
\hline
\end{tabular}

Source: http://www.iasc.in/products_services.html (accessed 1 May 2011).

* Authors' calculation. 
Table 15: Vimo SEWA's product main features

\begin{tabular}{|l|l|}
\hline Product name/type & Insurance (life, health, property, accidental) \\
\hline Description & Integrated insurance that covers death, illness, accidental injuries and property loss \\
\hline Motivation & Cover a range of risks affecting women \\
\hline Flexibility features & $\begin{array}{l}\text { - Voluntary membership } \\
\text { - Need-based, affordable product } \\
\text { - Integrated insurance scheme for the family } \\
\text { - Cashless system for illness coverage (through tie-ups with hospitals) } \\
\text { - Innovative premium payment plans such as fixed deposits and monthly instal- } \\
\text { ments } \\
\text { - Insurance linked to savings plan and loans }\end{array}$ \\
\hline $\begin{array}{l}\text { Financial discipline } \\
\text { features }\end{array}$ & $\begin{array}{l}\text { - For SEWA members and their families } \\
\text { - Limit on the type of risk insured, amount insured, etc. } \\
\text { - Premiums collected door-to-door or though self-help groups }\end{array}$ \\
\hline
\end{tabular}

Source: http:/ /www.sewainsurance.org (accessed May 2011); Churchill (2011).

\section{References}

Adams W D., 2009, "Easing Poverty Through Thrift", Savings and Development, Vol. 33, No. 1, pp. 73-85.

Amador M., I. Werning and G.M. Angeletos, 2006, "Commitment vs. Flexibility", Econometrica, Vol. 74, No. 2, pp. 365-396.

Aryeetey E. and W.F. Steel, 1995, "Savings Collectors and Financial Intermediation", Savings and Development, Vol. 19, No. 2, pp. 191-212.

Armendariz B. and A. Szafarz, 2011, "On Mission Drift of Microfinance Institutions", in The Handbook of Microfinance, B. Armendariz and M. Labie (Eds.), World Scientific Publishing, London, pp. 341-366.

Armendariz B. and J. Morduch, 2010, The Economics of Microfinance, MIT Press, Cambridge, MA, U.S.A.

Ashraf N., N. Gons, D. Karlan and W. Yin, 2003, "A Review of Commitment Savings Products in Developing Countries", ERD Working Paper, No. 45, Asian Development Bank.

Ashraf N., D. Karlan and W. Yin, 2005, "Deposit Collectors", Advances in Economic Analysis \& Policy, Vol. 6, No. 2, Art. 5. 
Ashraf N., D. Karlan and W. Yin, 2006, "Tying Odysseus to the Mast: Evidence From a Commitment Savings Product in the Philippines", Quarterly Journal of Economics, Vol. 121, No. 2, pp. 635-672.

BAAC, 2010, "Annual Report Fiscal Year 2009", Bank for Agriculture and Agricultural Cooperatives, Thailand. Available at http://www.baac.or.th/baac_en/contentreport.php?content_id $=000071 \&$ content_group $=0002 \&$ content_group_sub $=0003 \&$ inside $=$, accessed on 12 July 2011.

Barclays Bank, 2011a, "Effective Partnerships" [online]. Available at: http://group. barclays.com/Citizenship/Supportingour-communities/Increasing-access-tofinancial-services/Effective-partnerships, accessed on 11 July 2011.

Barclays Bank, 2011b, "Case Study: Microfinance in Emerging Markets" [online]. Available at: http://www.barclays.com/sustainabilityreport07/bmi_casestudy1. html, accessed on 11 July 2011.

Bauer M., J. Chytilova and J. Morduch, 2012, “Behavioural Foundations of Microcredit: Experimental and Survey Evidence from Rural India", American Economic Review, Vol. 102, No. 2, pp. 1118-1139.

BRI, 2010, “Annual Report 2009", Bank Rakyat Indonesia, Indonesia. Available athttp: / / media.corporate-ir.net/Media_Files/IROL/14/148820/2009Annual ReportBBRIsep10b.pdf, accessed on 3 August 2011.

Bryan G., D. Karlan and S. Nelson, 2010, "Commitment Devices", Annual Review of Economics, Vol. 2, No. 1, pp. 671-698.

Cadena X. and A. Schoar, 2011, "Remembering to Pay? Reminders vs. Financial Incentives for Loan Repayment", NBER Working Papers, No. 17020.

Center for Health Market Innovation, 2011, "Mamakiba" [online]. Available at http:/ / healthmarketinnovations.org/program/mamakiba-meaning-mothersavings?display=default, accessed on 3 August 2011.

CMF, n.d., "Indian Association of Savings and Credit, Tamil Nadu and Kerala", Centre for Micro Finance, Institute for Financial Management and Research, India. Available at http://ifmr.ac.in/cmf/wp-content/uploads/2008/02/iasc.pdf, accessed on 12 July 2011.

CGAP, 2000, "Exploring the Client Preferences in Microfinance: Some Observations from SafeSave", CGAP Focus Notes, No. 13.

CGAP, 2010, "Branchless Banking 2010: Who is Served? At What Price? What's Next?", CGAP Focus Notes, No. 66.

CGAP/IFAD, 2006a, "Managing Risk and Designing Product for Agricultural Microfinance: Features of An Emerging Model", IFAD Occasional Papers, No. 11. Available at http://www.ifad.org/ruralfinance/pub/risks.pdf, accessed on 12 July 2011.

CGAP/IFAD, 2006b, “Emerging Lessons in Agricultural Microfinance: Selected Case Studies". Available at http://www.ifad.org/ruralfinance/pub/case_studies.pdf, accessed on 12 July 2011. 
Chaudhury I.A. and I. Matin, 2002, “Dimension and Dynamics of Microfinance Membership Overlap - A Micro Study from Bangladesh", Small Enterprise Development, Vol. 13, No. 2, pp. 46-55.

Churchill C., 2011, "Insurance for the Poor: Definitions and Innovations", in The Handbook of Microfinance, B. Armendariz and M. Labie (Eds.), World Scientific Publishing, London, pp. 537-562.

Collins D., J. Morduch, S. Rutherford and O. Ruthven, 2009, Portfolios of the Poor. How the World's Poor Live on 2\$ a Day, Princeton University Press, Princeton, NJ, U.S.A.

Copestake J., 2007", Mainstreaming Microfinance: Social Performance Management or Mission Drift", World Development, Vol. 35, No. 10, pp. 1721-1738.

CRISIL, 2008, "Indian Association for Savings and Credit - MFI Credit Report".

Dowla A. and D. Barua, 2006, The Poor Always Pay Back: The Grameen II Story, Kumarian Press Inc., Bloomfield, Connecticut, U.S.A.

Equity Bank, 2011, “M-Kesho" [online]. Available at http://www.equitybank.co.ke/ products.php?subcat=128, accessed on 3 August 2011.

FAI, ideas42 and International Finance Corporation, 2011, "Emergency (hand) Loan", Financial Access Initiative Product Case. Available at

http:/ / financialaccess.org/sites/default/files/PC1_Emergency_Hand_Loan.pdf, accessed 12 July 2011.

FAO, 2003, "Term Financing in Agriculture: A Review of Relevant Experience", FAO Occasional Papers, No. 14.

Field E. and R. Pande, 2008, "Repayment Frequency and Default in Microfinance: Evidence from India", Journal of the European Economic Association, Vol. 6, No. 2-3, pp. 501-509.

Field E., R. Pande, J. Papp and N. Rigol, 2011, “Term Structure of Debt and Entrepreneurship: Experimental Evidence from Microfinance", Manuscript, Harvard University, Princeton University and MIT, U.S.A.

Fischer G. and M. Ghatak, 2010, "Repayment Frequency in Microfinance Contracts with Present-Biased Borrowers", Manuscript, London School of Economics, U.K.

Gmimano, 2010, "Project Name: Mamakiba (Meaning Mother + Savings)" [online]. Available at https://bitbucket.org/gmimano/mamakiba/wiki/Home, accessed 11 July 2011.

Guérin I., 2011, "The Gender of Finance and Lessons for Microfinance", in The Handbook of Microfinance, B. Armendariz and M. Labie (Eds.), World Scientific Publishing, London, pp. 598-612.

Hudon M. and A. Périlleux, 2010, "What Explains Microfinance Distribution Surplus? A Stakeholder-Oriented Approach", CEB Working Papers, No. 10-045, Université Libre de Brussels, Belgium.

IFAD, n.d., "Ghana - Informal Financial Services for Rural Women in the Northern Region" [online]. Available at http://www.ifad.org/gender/learning/sector/finance/41.htm, accessed 11 July 2011. 
Jain S. and G. Mansuri, 2003, “A Little at a Time: The Use of Regularly Scheduled Repayment in Microfinance Programs", Journal of Development Economics, Vol. 72, No. 1, pp. 253-279.

Jeon D.-S. and D. Menicucci, 2011, "When is the Optimal Lending Contract in Microfinance State Non-Contingent?", European Economic Review, Vol. 55, No. 5, pp. 720 731.

Johnson S., 2004, "Gender Norms and Financial Markets: Evidence from Kenya", World Development, Vol. 32, No. 8, pp. 1355-1374.

Johnson S., 2005, "Gender Relations, Empowerment and Microcredit: Moving on from a Lost Decade", European Journal of Development Research, Vol. 17, No. 2, pp. 224-248.

Karlan D. and S. Mullainathan, 2006, "Is Microfinance Too Rigid?", Centre for Micro Finance, Institute for Financial Management and Research, India.

Karlan D., M. McConnel, S. Mullainathanand J. Zinman, 2010, "Getting to the Top of Mind: How Reminders Increase Saving", NBER Working Papers, No. 16205.

Labie, M. (2009), "Microfinance: Evolutions du Secteur, Diversification de Produits et Gouvernance", Reflets et Perspectives de la Vie Économique, Vol. 48, No. 3, p. 5-6.

Laibson D., 1997, "Golden Eggs and Hyperbolic Discounting", Quarterly Journal of Economics, Vol. 112, No. 2, pp. 443-477.

Laureti C., 2012, "Flexibility and Payment Discipline in Microfinance", Manuscript, Université de Mons and Université Libre de Bruxelles, Belgium.

Mas I., 2010, "M-Kesho in Kenya: A New Step for M-Pesa and Mobile Banking" [online]. Available athttp:/ / financialaccess.org/node/2968, accessed 11 July 2011.

McIntosh C., 2008, "Estimating Treatment Effects Form Spatial Policy Experiments An Application to Ugandan Microfinance", Review of Economics and Statistics, Vol. 90, No. 1, pp. 15-28.

Meyer R.L., 2002, "The Demand for Flexible Microfinance Products: Evidence from Bangladesh", Journal of International Development, Vol. 14, No. 3, pp. 351-368.

Microfinance Gateway, 2010, "Innovation in Savings Services in Rural Sub-Saharan Africa" [online]. Available at www.microfinancegateway.org/p/site/m/template.rc/1.26.14353/, accessed on 11 July 2011.

Oleh Donald Banjarnahor, 2011, “BRI Manages IDR 290.58 trillion fund” [online], Bisnis Indonesia. Available at http:/ / www.bisnis.com/business/22691-bri-managesidr29058-trillion-fund, accessed on 6 July 2011.

Osei R.D., 2007, “Linking Traditional Banking with Modern Finance: Barclays Microbanking Susu Collectors Initiative", UNDP. Available at http:/ / www.growinginclusivemarkets.org/media/cases/Ghana_Susu\%20Collectors_2008.pdf, accessed on 11 July 2011.

Pagura M.E. and M. Kirsten, 2006, “Formal-Informal Financial Linkages: Lessons from Developing Countries", Small Enterprise Development, Vol. 17, No. 1, pp. 16-29. 
Pickens M., 2010, “Where Will the Next Mobile Money Innovation Come From?” [online], CGAP. Available at http://technology.cgap.org/2010/11/18/where-willthe-next-mobile-money-innovation-come-from/, accessed 12 July 2011.

Radcliffe D., 2010, “Expanding Customers' Financial Options Through Mobile Payment Systems: The Case of Kenya", Bill \& Melinda Gates Foundation Global Savings Forum. Available at http://www.gatesfoundation.org/financialservicesforthepoor/Documents/expanding-customers-financial-options.pdf, accessed 12 July 2011.

Ravi S., 2006, “Repay As You Earn”, Working Paper, Indian School of Business, India.

Rutherford S., 2000, The Poor and Their Money, Oxford University Press, New Delhi.

Rutherford S., 2011, "Boosting the Poor Capacity to Save: A Note on Instalment Plans and Their Variants", in The Handbook of Microfinance, B. Armendariz and M. Labie (Eds.), World Scientific Publishing, London, pp. 517-536.

Sadoulet L., 2002, “Incorporating Insurance Provisions in Microfinance Contracts, Learning from Visa ${ }^{\circledR}$ ?", WIDER Discussion Papers, No. 56, United Nation University, Finland.

Safaricom, 2010, "M-Pesa Customer and Agent Numbers" [online]. Available athttp:/ / www.safaricom.co.ke/fileadmin/M-PESA/Documents/statistics/MPESA_Statistics_Jan2011.pdf, accessed 11 July 2011.

Saila C., 2010, "Agricultural Value Chain Financing” [online]. Available at www.adfiap.org/wp-content/uploads/2010/12/Dr.-Chavarin-Saila.ppt, accessed 11 July 2011.

Schicks, J., 2010, “Microfinance Over-Indebtedness: Understanding its Drivers and Challenging the Common Myths", CEB Working Papers, No. 10/048, Université Libre de Bruxelles, Belgium.

Schreiner M., 2004, "Benefits and Pitfalls of Statistical Credit Scoring for Microfinance", Savings and Development, Vol. 28, No. 1, pp. 63-86.

Seibel H.D, A. Rachmadi and D. Kusumayakti, 2010, "Reform, Growth and Resilience of Savings-Led Commercial Microfinance Institutions: The Case of the Microbanking Units of Bank Rakyat Indonesia", Savings and Development, Vol. 35, No. 3, pp. 277-303.

Shoji M., 2010, “Does Contingency Repayment in Microfinance Help the Poor During Natural Disaster?", Journal of Development Studies, Vol. 46, No. 2, pp. 191-210.

Strotz R.H., 1955, "Myopia and Inconsistency in Dynamic Utility Maximization”, Review of Economic Studies, Vol. 23, No. 3, pp. 165-180.

Tedeschi G.A., 2006, “Here Today, Gone Tomorrow: Can dynamic incentives make microfinance more flexible?", Journal of Development Economics, Vol. 80, No. 1, pp. 84-105.

Thaler R.H, 1985, "Mental Accounting and Consumer Choice", Marketing Science, Vol. 4, No. 3, pp. 199-214. 
Townsend R.M. and J. Yaron, 2002, “An Asian Development Bank: Credit Risk-Contingency and the Subsidy Dependence Index", Savings and Development, Vol. 26, No. 3, pp. 227-258.

ViganòL., 1993, "A Credit-Scoring Model for Development Banks: An African Case Study", Savings and Development, Vol. 17, No. 4, pp. 441-482.

VSSU, 2009, "Annual Report 2008-09", Vivekananda Sevakendra Sishu Uddyon, India. Available at http://www.vssu.in/pdfs/VSSU\%20Annual\%20Report $\%$ 202008-09.pdf, accessed on 6 July 2011.

Wajananawat L., 2010, "World Food Security and Rural Financing: The Case of BAAC", paper presented to the Third Word Congress on Rural and Agricultural Financing, Marrakech, Morocco, 28-30 October 2010. Available at http:/ / www.apraca.org/content_detail.php?cid=2174, accessed on 26 September 2011.

Woller G., 2002, "From Market Failure to Marketing Failure: Market Orientation as the Key to Deep Outreach in Microfinance", Journal of International Development, Vol. 14, No. 3, pp. 305-324.

\section{List of websites}

Bank of Agriculture and Agricultural Cooperative (BAAC) www.baac.or.th

Bank Rakyat Indonesia (BRI) www.bri.co.id

Barclays Bank http:/ /group.barclays.com/Home

Banco Los Andes Pro Credit www.losandesprocredit.com.bo

Confianza www.financieraconfianza.pe

Equity Bank http:/ / www.equitybank.co.ke/products.php?subcat=128

Financial Access Initiative http:/ / financialaccess.org/node/2968

Financial Technology Africa www.financialtechnologyafrica.com

Kilimo Salama http:/ / kilimosalama.wordpress.com/about/

Indian Association for Savings and Credit www.iasc.in

International Law Organization (ILO) Microinsurance Facility www.ilo.org/microinsurance

Islamic Finance Asia www.islamicfinanceasia.com

Mamakiba https://bitbucket.org/gmimano/mamakiba/wiki/Home

PT Bank Syariah BRI www.brisyariah.co.id

Safaricom www.safaricom.co.ke

SafeSave www.safesave.org; www.thepoorandtheirmoney.com

VimoSEWA www.sewainsurance.org

ShohozShonchoy www.thepoorandtheirmoney.com

Vivekananda Sevakendra Sishu Uddyon (VSSU) www.vssu.in 


\section{Résumé}

Cet article décrit une série de produits de microfinance innovants qui combinent deux caractéristiques importantes pour les clients pauvres : la flexibilité et la rigueur financière. Il s'agit de produits de micro-épargne, de microcrédit et de micro-assurance proposés par des institutions de microfinance dans le monde entier. Cette analyse montre que les fournisseurs de services offrent différents types de flexibilité dans les contrats financiers et que la flexibilité peut être combinée à une variété de mécanismes encourageant la discipline, tels quele dépistage et la surveillance directe des clients, la garantie financière, les incitants relatifs à la réputation, et aussi la pression psychologique. Nous remarquons cependant que la flexibilité peut impliquer une augmentation des coûts opérationnels des institutions et n'a toutefois qu'une portée limitée. 
